\title{
Cowardice and Military Security: Some Heuristic Reflections
}

\author{
Andreas Vasilache ${ }^{1}$
}

Received: 5 December 2019 / Accepted: 11 April 2020 / Published online: 2 May 2020

(c) The Author(s) 2020

\begin{abstract}
While cowardice is sanctioned by military law in most countries, the impact of cowardice on modern warfare and security politics is low. This might be the reason why cowardice - as notion, phenomenon, and topic - has widely been neglected in security studies. However, for quite some time, we have witnessed a revival of the word as an accusation and pejorative term that is frequently applied by Western government representatives to describe the enemy in armed conflicts. The expression of a "cowardly attack" has become quite common in political communication after attacks against Western forces in violent confrontations. Thereby, cowardice is transformed from a possible weakness of the own forces to a particular strength of the enemy. This article aims at presenting some reflections on the notion, meaning, and functional role of cowardice in situations of violent international conflict, as well as on the use of the term as a speech act in recent governmental security communication. A particular focus will be put on the normative implications of the revival of the governmental cowardice-rhetoric.
\end{abstract}

Keywords Cowardice $\cdot$ Heroism $\cdot$ Post-heroic society $\cdot$ Security $\cdot$ Terrorism $\cdot$ Speech act

Andreas Vasilache

Andreas.Vasilache@uni-bielefeld.de

1 Bielefeld University, Bielefeld, Germany 


\section{Introduction ${ }^{1}$}

Cowardice is not given much consideration in International Relations (IR) or international security studies. In academic security discourses, cowardice plays hardly any role, neither as a concept nor as a phenomenon. When searching for the term and its derivations in current political and social sciences literature, only a few individual mentions appear, which are represented in a small number of articles and even there are marginal. The academic lack of interest in the subject of cowardice persists even though acts of "cowardice in the face of the enemy" are codified in the military law of most countries, including those in the West, and are punishable by severe sanctions. Actually, the disinterest in cowardice seems to be a general phenomenon and is obvious also when we broaden the view beyond the political and social sciences literature. Walsh (2014: 8, see also 167) undertook a statistical assessment based on the English Google books database from 1800 to 2008 and shows that over the last two centuries, the use of the words cowardice and of coward decreased by $80 \%$ and $50 \%$, respectively. At the same time, and in marked contrast to the long-term decline of the topic of cowardice, in recent governmental communication, the term and accusation of cowardice is quite often invoked to describe the actions of one's adversary. In situations of asymmetric conflicts or guerrilla warfare, government representatives and politicians commonly refer to the enemy's attacks and strategies as acts of cowardice. In this context, the term cowardice, as used both in everyday language and in the traditional military sense, connotes a particularly grievous form of shameful and dishonorable behavior.

In light of both the increasing attention paid to security in IR as a "framework for analysis" (Buzan et al. 1998) and the ever-growing range of new policies and practices of securitization, the scholarly lack of interest in considering cowardice in a more detailed and comprehensive way is surprising. ${ }^{2}$ This disinterest in cowardice is puzzling also because the role of emotions, and in particular of fear and anxiety, ${ }^{3}$

\footnotetext{
1 I would like to thank Randall Hansen for helpful comments on an earlier draft of this article. Basic lines of the following argumentation have been published in German language in Martinsen and Flügel-Martinsen (2014). An earlier draft of this article was presented at the conference "The great, small, middle power? German foreign policy between power politics, idealism, and muddling through" at the Centre for European, Russian, and Eurasian Studies (CERES) of the Munk School of Global Affairs \& Public Policy at the University of Toronto in May 2015.

2 As a notable exception, see the excellent book of Walsh (2014) for a history of the topic and idea as well as the usage and impact of cowardice. His broad and inclusive approach to the issue goes well beyond the more narrow focus of this article, which is concentrated on the functional role, changes, and normative implications of cowardice and cowardice-accusations for military security.

3 As the following discussion focuses not on fear and anxiety, but on cowardice, suffice it to say here that fear and anxiety are not identical phenomena, but can be distinguished from each other. The distinction is based on the cause and catalyst of fear and anxiety, the degree of certainty and immediacy involved, and the extent to which either state might affect the individual. Fear is associated with a specific situation or an object that can be named, which is not necessarily the case with anxiety. Søren Kierkegaard (1912: 36f) first introduced this conceptual distinction, which is mirrored also in the everyday use of the two terms. Owing to its higher degree of specificity, the term "fear" points to, and emphasizes, the phenomenon and cause that evokes fear, whereas the term "anxiety" point to, and emphasizes, the emotional state of the person afflicted.
} 
has received much attention in recent discourses on security policy. A growing body of research has outlined the impact of emotions in and for international politics (see Wolf 2012; Koschut 2015; Korte 2015) and has revealed the analytical and political relevance of fear, especially in connection with the study of transnational terrorism (see, e.g., Dillon and Reid 2009: 136; Hoffmann 2002: 51, 56, 197ff; Waldmann 1998: 10ff, 15, 19). Increasingly, the political implications of fear have also become the subject of recent research in various disciplines and areas, including political theory (Lentzos and Rose 2008; Selk 2011; Skoll 2010); the study of contemporary society (Barber 2002, 2003; Bauman 2006: 129-139, 158f); criminology (Bauman 2006; Garland 2002; Simon 2007); and IR, particularly in the field of international security studies (Booth and Wheeler 2008: 62-80; Dillon and Reid 2009: 85f, 136; Schneckener 2006: 21-23; Thrall and Cramer 2009).

The explicit focus on fear is a relatively recent development in both political theory and IR (along these lines, see also Booth and Wheeler 2008: 62). Yet even before the concept of fear began to be addressed in the current research, the political consequences of fear as a "primordial emotion" (Booth and Wheeler 2008: 79) played an important role in state theory and political philosophy. According to Thomas Hobbes, it is the perpetual fear of death in the anarchic state of nature that makes the establishment of statehood necessary and possible in the first place-and it is the subjects' fear of being punished by the sovereign that guarantees the continuity of the state (Hobbes 1998: 98, 105, 108, 131, 134, 155). In the field of IR, it is in particular the realist theory tradition "in which fear is central" (Booth and Wheeler 2008: 79). While this tradition is not interested primarily in the psychological fear of individuals, one core aspect of realist approaches is that they regard international politics as structurally characterized by mutual distrust and fear among states. Concepts such as the security dilemma, the belief that arms races are unavoidable for structural reasons, and realist deterrence doctrines all presuppose the strong and significant political impact of fear. One could even say that realist thinking is so much focused on fear as to sometimes lead to "ideological fundamentalism" (Booth and Wheeler 2008: 79, 64f, 78).

However, cowardice is a phenomenon that has not been discussed in these discourses on fear, anxiety, and politics. Its impact on security has widely been neglected. Given that cowardice has barely been addressed in IR and international security studies, the following considerations aim at presenting some general and still tentative reflections on the notion and political function of cowardice in military security as well as on the relation between cowardice, recent ubiquitous cowardiceallegations, and security within the context of armed conflicts. Since the instrumental use of governmental cowardice-accusations is quite obvious, I will not concentrate on the propagandistic and cathartic aspect of this imputation (for emotions in (international) politics and IR see again Wolf 2012; Koschut 2015; Korte 2015). Likewise, the following discussion does not focus on terrorism or on the question of whether terrorist attacks may, by definition, be regarded as acts of cowardice, and if so, in what sense. Instead, I will trace some changes of the meaning, connotation, and functional role of cowardice in violent, war-like confrontations as well 
as in recent security communication strategies of Western governments. ${ }^{4}$ While I will draw on empirical references-mainly public statements from government representatives, mostly from the German context-in order to exemplify and illustrate the arguments made, the following considerations are not an empirical contribution, but a conceptual heuristic approach to think about the relation between cowardice and military security in general and about the implications of perpetuated cowardice-accusations in particular. Thus, the argument brought forward in this article is not based on broad empirical research, but can be regarded as a proposal for future empirical investigations.

In the first step, I will present some brief considerations on the concept of cowardice, gauge its relationship to military combat, and discuss its codification in military law. After these reflections, I will discuss how the relevance and functional role of cowardice have changed - and declined-in Western military security rationalities and policies. Building on this, the following section covers the recent revival of cowardice that has taken the shape of repetitive and knee-jerk cowardice-accusations. In this part, the return of cowardice will be discussed with regard to its functions in, and its implications for, current rationalities and understandings of military security, while paying particular attention to the normative consequences of this revival.

\section{The Concept of Cowardice, its Relation to Military Combat, and its Legal Codification}

Since cowardice is a term that has rarely been used in political science and IR, it is not only useful but necessary to start this section with a brief discussion of how it is understood in everyday language and to provide a systematic definition of the term. What is most notable about the notion of cowardice is that its scope and meaning have remained relatively stable over the past 100 years. The 4th edition of Meyers Konversations-Lexikon, the most comprehensive German encyclopedia of the 19th century, defined cowardice as "a habitual state of the mind in which man avoids peril or pain to such a degree that his freedom and determination are benumbed and his sense of honor and disgrace is blunted. The opposite of c. is courage [...]. C. is also used to denote a military offense in which a soldier shirks his duties for fear of personal injury or harm" (Meyers Konversationslexikon 1885-1892: 100, own translation). Likewise, the 14th edition of the Brockhaus encyclopedia described cowardice as "the tendency to let one's action be determined by fear. Military c. consists in the dereliction of a military duty for fear of personal harm" (Brockhaus' Konversationslexikon 1893-1897: 632f, own translation). A century later, cowardice

\footnotetext{
${ }^{4}$ Concentrating on the question of cowardice in connection with military conflicts implies a systematic focus on one particular area of security policy, namely the sector of organized military violence. However, this does not imply that the following considerations are based on a traditional and narrow concept of security, in which security is equated with military power. Rather, this narrower and concrete focus reflects a thematic decision to highlight a specific sector that continues to play an important role in security policy (Buzan and Hansen 2009: 12f, 21f, 25).
} 
is defined by the DTV-Lexikon as "the quality opposite to courage usually motivated by fear rather than by moral considerations", with special emphasis on the fact that "c. 'in the face of the enemy' [...] is a punishable offense in all armed forces" (DTVLexikon 1992: 252, own translation).

The phenomenological definitions offered in these encyclopedias emphasize six aspects that are characteristic of cowardice, as well as a seventh aspect that is closely related to it. Firstly, cowardice is defined as a mental characteristic or tendency in the sense of a psychological phenomenon. Secondly, particular emphasis is placed on the relationship between fear and cowardice. Cowardice is described as a particular way of dealing with fear, a way in which individuals allow their actions to be determined by the mental and emotional states of fear and anxiety and thus give into them. Related to the second aspect, cowardice is, thirdly, understood to be the negative correlate of courage and determination. As Casebeer (2004: 444) puts it in reference to Aristotle, "the extremes of cowardice (which consists in possessing an excess of fear) and foolhardiness (which consists in having a deficiency in fear)" are detrimental to bravery. As a result, cowardice is, fourthly, associated with a tendency to inhibit, to paralyze, and to benumb. This effect is also at the heart of Kierkegaard's conceptual and phenomenological definition of cowardice. As one of the few modern philosophers to have written on the concept of cowardice at all, albeit with an eschatological objective in mind and for Christian edification (Mullen 1988: 3), Kierkegaard placed cowardice in opposition to "making a decision, or the resolve to make a decision" (Kierkegaard 1962: 57, see also 82, 85-88, 91f) and identified it as "the archenemy of resolve" (Kierkegaard 1962: 65). Fifthly, and an aspect that is immediately related to the inhibiting effect of cowardice, it is seen as a phenomenon that weakens the individual. With determination inhibited, the coward becomes restricted in terms of being free to act and is thus deemed a weakling. Sixthly, cowardice clearly has a negative connotation. It is by no means understood to be a way of dealing with real or perceived risks in a careful, provident, or considerate manner. Rather, cowardice is an unambiguously derogatory term for an objectionable disposition, motivation, or basis for action or inaction. It follows from the definitions outlined above — as well as from Hobbes' (1998: 169) and Kierkegaard's (1962: 67) considerations - that the negative connotations of cowardice are both highly specific and particularly forceful and defamatory in that the term conveys an insult to the honor of the person so described, as well as moral disapproval and contempt. ${ }^{5}$ The seventh aspect - that is not a characteristic trait of cowardice but closely related to it-consists in its relation to military security. Walsh recognizes war to be the "archetypal setting" of cowardice (2014: 167) and notes that "the cowardly soldier remains the poster boy, so to speak, for cowardice" (2014: 14). ${ }^{6}$ As reflected also in the explicit reference to military security in the encyclopedic definitions quoted

\footnotetext{
${ }_{5}^{5}$ Iyer (1986: 83) outlines that Gandhi strongly disapproved that nonviolence be based on cowardiceand that for Gandhi "[b]etter far than cowardice is killing and being killed." See also Lummis (2006: 324-326) and Parekh (1988: 214) for a discussions of Gandhi's take on violence in relation to his rejection of cowardice.

${ }^{6}$ See Walsh (2014: 100-130) for an intense discussion of the relation between cowardice and the idea and concept of (military) duty.
} 
above, there seems to be a direct connection between cowardice and military security. Cowardice is presented as an issue that has long been, and still is, addressed by military organizations and that requires legislative and judiciary consideration and regulation.

The intrinsic relation between cowardice and military security is particularly noteworthy because it reveals a distinction between cowardice and other personal peculiarities that are merely regarded as individual character flaws. The first six characteristic aspects show that cowardice is an individual phenomenon that elicits social rejection and contempt. However, unlike other individual dispositions and traits considered to be reprehensible (such as excessive selfishness, vanity, or prejudice), cowardice is considered to be relevant not only on an inter-individual or societal level, but to have direct implications in the context of (national) security. As Sharp (1968: 201) puts it, "[i]t has been commonly believed that the alternative to war is impotence, cowardice and passive submission." Unlike other negative character traits, it is not only the potential harm and consequences caused by cowardly behavior, but also cowardice itself that seems to be important in the field of military and security policy - and as such is codified and sanctioned by legislation. ${ }^{7}$ Efforts to curb cowardly conduct in the armed forces play a role in a variety of punishable offenses against military law, such as desertion, absence without leave, and refusal to obey a lawful order, while cowardice is also directly and explicitly enshrined in law.

Taking a look at military law, we see that the legal concept of "cowardice in the face of the enemy" is not simply of historical importance, despite the somewhat anachronistic flavor of the expression. For instance, according to the German Military Penal Code (Wehrstrafgesetz (WStG), "fear of personal danger [...] does not excuse an offense if it is the duty of the soldier to face such danger" (WStG 1957: $\S 6$, own translation). Explicit reference to cowardice is made in the United States Uniform Code of Military Justice (UCMJ), which defines acts of "[m]isbehavior before the enemy" (UCMJ, 64 Stat. 109, 10 USC, Subchapter X, § 899, Art. 99) and which states that "[a]ny member of the armed forces who before or in the presence of the enemy [...] is guilty of cowardly conduct [...] shall be punished by death or such other punishment as a court-martial may direct" (UCMJ: 64 Stat. 109, 10 USC, Subchapter X, § 899, Art. 99). As Weitz (2012) puts forward, cowardice was a crime severely punishable already on both sides in the American civil war. Cowardice is also explicitly mentioned in the Swiss Military Penal Code (Militärstrafgesetz. $(M S t G)$, which states that anyone "who out of cowardice in the face of the enemy hides, flees, or abandons his post without authorization to do so is punished with life imprisonment or imprisonment" (MStG 1927: Art. 74). In order to give some more illustrative examples, cowardice in face of the enemy is codified and punishable also

\footnotetext{
7 For the purposes of this article, suffice it to say that Hobbes is critical of the legal sanctioning of cowardice and that he made a very precise distinction between the social and the legal assessment of cowardice. Hobbes states that the question of cowardice might have important implications for national security. However, based on his systematic argumentation methodology, he regards cowardice in combat as dishonorable, but not unlawful because the individual right to self-preservation cannot be restricted (Hobbes 1998: 169, 231).
} 
in the Czech Penal Code (Weiss 2012: 459) and in the Pakistan Army Act (Khattak 1996: 347).

These military offenses are not just juridical anachronisms (see accordingly Brinkkötter 1983: 196-199), nor should it be assumed that the provisions just cited are outdated and only have historical relevance. Such an assumption is contradicted by the fact that the UCMJ allows the death penalty - actually, mentions it as the first possible form of punishment. Taking into account the highly controversial debates on capital punishment in the USA, we can rule out the possibility that this regulation in the UCMJ has just gone unnoticed until now. In addition, the cowardiceparagraph 74 of the Swiss Military Penal Code was revised as recently as 1992 and has only been in effect in its current form since then, while the 2009 reform and tightening of the Czech Penal Code has recently reaffirmed the crime of cowardice facing the enemy (Weiss 2012: 459). However, the main reason why it would be misleading to regard the codification of cowardice in military law of democratic states as mere anachronisms consists in the fact that liberal democracies are in particular need for legal provisions emphasizing the obligation of servicepersons to face danger even if this is likely to cause them personal harm. For, unlike political systems and societal contexts in which little weight is given to individual freedom, liberal democratic rule is, not least, based on civic liberties, individual rights, and the principle of personal self-determination. In liberal democracies, the individuals' rights and preferences have to be taken seriously by their government, whose power over its citizens - and in particular over their right to physical integrity-is limited. Democracies cannot take for granted that individuals agree to governmental decisions to go to war-or that they agree, or just can be ordered by governments, to put their lives at risk. Expecting that individuals will enlist for military service just because of a governmental decision, and that they will not escape and seek shelter in the face of death just because of a political order, is not consistent with the principles of a limited government and law-based order that puts the individual in its center. Thus, precisely because of the exceptional legal and empirical character of such a situation-which "has as its opponent nothing less than the elementary instinct of self-preservation" (Brinkkötter 1983: 1, own translation)—specific legal provisions constituting and penalizing particular defeatist manifestations of self-preserving behavior are in fact needed, not exclusively, but most importantly in the law of liberal democratic states. Since governments in liberal democratic societies cannot exercise arbitrary power over the lives of their citizens as they see fit, nor can they simply assume that cowardice will be roundly condemned by society, formalized, legally codified, and enforceable restrictions on the individuals' right to self-determination and self-preservation are an imperative necessity for the existence of an army. Thus, the necessity in liberal states and societies-as long as they choose to have armed forces - to legally codify and legitimize that free individuals are forced to face the risk of death contradicts the assumption that the concept of cowardice in military law is a mere anachronism.

Keeping in mind these brief reflections on the concept of cowardice and the discussion of its codification in military law, we can now proceed to explore the material and discursive role of cowardice in and for military security. The considerations that follow are based on the understanding of cowardice as outlined above. 


\section{The Historical Impact of Cowardice for Military Security and its Loss of Significance}

Cowardice continues to be a relevant issue in democratic countries as long as they choose to have an army. Cowardice is sanctioned by military law because obligating individuals to face danger and possibly death is in need of particular and cogent justification and codification. However, as outlined by Brinkkötter (1983), in a historical perspective, the issue of cowardice has been regarded to have also strategic implications and implications for security and military policy. As mirrored in the legal codification of cowardice as a military offense, cowardice has usually been seen as a risk for the military morale and the strength of the own armed forces. One example of the historical relevance attributed to the problem of cowardice within the own troops is the practice of decimation, a form of disciplinary measure in use from the time of the Roman Empire to the early modern period, that in some cases led to the killing of entire regiments. The view that cowardice is a risk for national military security becomes obvious also when, as Khattak (1996: 347) puts it with regard to Pakistan, "these incidents are hushed up, ostensibly to prevent morale from falling-or, it might be said, to prevent masculinist culture and myths from being punctured". 8 Another example of the relation between national security and cowardice comes to the fore in those parts of realist thinking in IR that equate appeasement policies with cowardice (cf. Azubuike 2006: 50, 64). Finally, the importance attributed to cowardice as a risk for own military power is reflected also in the widespread social condemnation of pacifist views immediately before the outbreak of the First World War and the prevalent, unmitigated enthusiasm for narratives about military heroism and soldiers who cheerfully marched to their death.

However, in contrast to its historical significance and to its ongoing legal relevance, we can note that today, neither the risk of cowardice among the armed forces nor the issue of cowardice itself seems to play a significant role in Western security rationalities or in military security policies. Cowardice in the sense outlined above does no longer seem to have a functional place in the security strategies, policies, and politics of Western societies. Even though it is of course still possible that own troops are accused of cowardly behavior ${ }^{9}$ and although the issue of cowardice continues to be codified and sanctioned by law, its continued legal relevance appears to be limited to the individual dimension of cowardly behavior and to the threat of punishment of individual soldiers for offenses such as insubordination, lack of willingness to fight, or absence without leave. It seems that cowardice is not regarded to have a collective dimension or to be functionally relevant for military security policy any more. Cowardice seems to play a role only on the level of individual cases of

\footnotetext{
${ }^{8}$ Höglund (2003: 243) hints at the gendered construction of character traits in heroic myths: "This becomes particularly clear in military education, where certain desirable properties that are classed as masculine are encouraged and rewarded (e.g., duty), while at the same time other-undesirable'feminine' properties are discouraged (e.g., cowardice, softness, weakness)."

9 For such reproaches in the Netherlands toward the Dutch peacekeeping mission in Bosnia see Sion (2006: 457), for accusations of cowardice to the Belgian peacekeepers in Rwanda see Blocq (2010: 291, $300,304)$.
} 
dereliction of official duty or, as one might characterize it in the case of volunteer professional armies, as a breach of the employment contract.

Actually, there are both cultural and structural reasons why cowardice does no longer play the role it once did in Western security policies and why it is now relevant mainly as an individual's violation of the law. Given that narratives of military heroism and self-sacrifice have largely lost their function in "post-heroic societies" (Münkler 2007: 742, own translation), it actually is not surprising that cowardice, which is the negative correlate of such narratives, is losing its relevance as well. Cowardice can become an important issue of security policy only in contexts in which national security is based primarily on ideas of military valor, heroism, and soldierly honor. Cowardice can, and indeed must be, considered a serious threat in security cultures ${ }^{10}$ in which individual and collective courage and self-sacrifice among the armed forces are regarded as both the condition and the primary source of military strength and national security. This is why in heroic postwar national "[m]yth creation [...] episodes of cowardice, internal conflicts and collaboration are forgotten or reinterpreted" (Hutchinson 2009: 411; see also Khattak 1996: 346f). In "heroic societies" (Münkler 2007: 742, own translation), cowardice has to be seen as a major security challenge because it undermines the very foundations of national security. But, just as discourses of heroism and self-sacrifice have lost their relevance in debates about security and security policy in Western societies, so has the potential threat posed by cowardice. In short, there is no functional or material place for the military hero in a post-heroic security culture, nor is there any place in such a security culture for "cowardice in the face of the enemy"-at least not on the macro-level of national security policy. This is why, prosecution of cowardly conduct, as well as its opposite, recognition in the form of military decorations, in most Western, post-heroic societies, do not seem to be of much interest outside the army. The question of cowardice is, at best, limited to the military sub-system and its internal communication and is directed only to the individual-one might even say personal-level in order to deal with individual cases of dereliction of official duty.

Not least owing to the experience and collective memory of a militarized society and politics with its catastrophic consequences, in today's German society, there is particular skepticism about myths of military heroism. This is reflected in an almost complete public absence of any traces of military and soldiery culture. For instance, large military tattoos today hardly receive any public attention in German society outside the armed forces. Rather, they are treated with great indifference and seem to be perceived mainly as a folkloristic anachronism. But even in societies that are less troubled by a history of aggressive militarism and in which military rituals play a more important role, ${ }^{11}$ the guiding principles of national security policy-or even just those of military policy—are no longer virtues such as heroism, valor, and

\footnotetext{
${ }^{10}$ For detailed discussions of the concept of security culture, see Daase et al. (2012), Katzenstein (1996), and Kleinschmidt (2009).

11 An example that comes to mind is Veterans Day, a major holiday in the political culture of the USA. Cramer refers to ritualized phenomena of this kind in the USA as "militarized patriotism" (2009: 135), though without substantiating her rather broad and sweeping claim that "the United States shares a militarized political culture" (2009: 151).
} 
self-sacrifice that could be threatened by cowardice as the opposite form of conduct. In fact, there is a far-reaching general consensus in Western societies that today, wars are neither won by heroism nor lost by cowardice.

An important factor that has contributed to the loss of relevance of heroism, selfsacrifice, and cowardice to security policy is the widening of the notion and understanding of security. There has been an increasing shift in the focus of security policy away from the traditional, and more or less exclusive, concentration on the state and on military violence toward the inclusion of an ever-growing number of issues and actors that are today perceived to be security-relevant (Buzan et al. 1998: 207; see also Buzan and Hansen 2009: 187-189, 272). Just as the state and the military have been losing their exclusive conceptual and political roles in the area of security policy, narratives about self-sacrifice, honor, courage, and cowardice continue to lose their relevance. These narratives have their origin in the discursive space of military culture and are meaningful only in connection with soldierly combat. In the context of a broader, non-traditional understanding of security, such ideals and narratives serve hardly any purpose and do not make sense any more.

Instead of heroism, contemporary Western discourses about, and practices of, security and military policy are characterized by ideals of technological superiority, efficiency, and specialization and increasingly involve risk assessment and instrumental cost-benefit analysis. The observation that the guiding principles, discourses, and practices of security policy today are shaped by logics of biopolitical risk management and technical supremacy has been addressed by various approaches, most notably those inspired by governmentality theory (e.g., Dillon and Neal 2008; Dillon and Reid 2009; Jabri 2006; Kienscherf 2011; Vasilache 2019a). Studies in this area have shown that the governmental logics of security are guided by a political economy of risk assessment as well as strategies of risk minimization and resilience (Aradau and Van Munster 2007) and are pervaded by rationalities of expediency and Ordungspolitik (Grondin 2010; Valverde and Mopas 2004). Taking into account that Western security policies and dispositifs today are guided by, and embedded into, the rationalities of an all-encompassing political economy (e.g., Aradau and Blanke 2010; Kiersey 2010, 2011), it becomes obvious that there is hardly any functional place in current security policy for narratives of heroism or cowardice.

An example that illustrates that and how security policies today are governed mainly by technological and economic rationalities is the Strategic Guidance released by the US Department of Defense (DoD) in January 2012 (see Vasilache 2014). A document without the slightest trace of heroic rhetoric, it emphasizes the role of "maintaining intellectual capital" in the department's efforts "to expand key elements of the force" and "the vectors on which we place our industrial base, our people, our active-reserve component balance," which are "a key part of our decision calculus" (DoD 2012: 6-8, emphasis in original). With regard to the long-term objectives of US security and military policy, the strategy paper highlights that "the Department will make every effort to maintain an adequate industrial base and our investment in science and technology" and "to sustain key streams of innovation that may provide significant long-term payoffs" (DoD 2012: 8). The Strategic Guidance further states that a "globally networked approach to deterrence and warfare" is needed and highlights that "the health and quality of the All-Volunteer Force" (DoD 
2012: 8) has to be ensured. Such a focus on the well-being of the workforce as basis for the quality of the military personnel corresponds to the ongoing attempt to make the German army a more family-friendly workplace, i.a., by establishing child care facilities in Bundeswehr barracks (Der Spiegel 2014). The fact that logics of military professionalism and health care have taken precedence over ideals of sacrifice and bravery is reflected also in the reassessment of specific military- and war-related phenomena. As an example, one could name "the invention of PTSD [posttraumatic stress disorder, A.V.]" that made "trauma no longer a mark of malingering or cowardice" (Neocleous 2012: 193).

In addition, the decline of a traditional, heroic security culture and the loss of significance of narratives of soldiery sacrifice, national heroism, and cowardice is mirrored in, and further advanced by, the rise of private military and security companies that today build an important part of Western warfare (see Alexandra et al. 2008; Friedrichs 2010; Schneiker 2010; Tonkin 2011.) Obviously, heroic self-sacrifice and the prospect of military honor and recognition cannot be expected to be the major factors in an individual's decision to join a private army as a mercenary or to work for a private military company. Rather, the decision to sign on in a private military company will be the result of an individual, instrumental economic assessment of costs, risks, and benefits. The privatization of security has various serious, often unsavory, and, as Friedrichs (2010) rightly notes, predictable negative consequences that require, at the very least, strict monitoring and control of the companies and actors involved (see Schneiker 2010; Tonkin 2011). However, the privatization of military services corresponds well to the political rationality of a post-heroic security culture, which perceives military force mainly as a technological and professionalized task-and is largely devoid of ideas of self-sacrifice, heroism, and military honor. In fact, both the client and the contractors are united by post-heroic goals and logics. States and societies employing private military companies obviously prefer the externalization — and, to a considerable degree, the veiling —of military risks to the pursuit of soldiery challenges and glory. At the same time, mercenaries definitely do not want to die as heroes. Having said this, the rise of private military companies and their deployment by Western states in violent conflicts corresponds well to Münkler's observation that "very few societies in which 'new wars' are fought can be considered to be heroic societies" (2007: 744, own translation).

\section{The Revival of Cowardice in Governmental Security Communication and its Normative Implications}

The fact that cowardice has lost its functional role in security policies of Western states and societies might explain why it is not systematically considered in societal or academic discourses. However, in contrast to its declined relevance, the terms cowardice and cowardly have recently been revived and are used-in an undefined and indistinct manner-as pejorative terms to characterize the enemy in various armed conflicts. In fact, Western politicians-and patriotic tabloid media-use phrases referring to cowardice almost reflexively in public statements and comments when reacting to an enemy's attack. Thereby, it is remarkable that 
the expression of a cowardly attack does not only appear after attacks on civilians or after terrorist attacks in areas free from military confrontations-but also whenever own or allied troops are attacked in a war zone. Conjuring up to the underhandedness and wickedness of the attack, the accusation of cowardice seems to be made regardless of the situation, place, addressees, and victims, or of the assaulter's behavior and acceptance of the own death in the attack. ${ }^{12}$ In short, the reproach of cowardice by Western governments is by no way restricted to terrorist attacks within the own countries, but governments are quick to use this formulaic phrase to condemn the strategies and tactics of enemy combatants in situations of asymmetric military conflicts such as in Afghanistan, Iraq, or Syria. This revival of the rhetoric of cowardice in connection with armed conflicts, connoting the enemy's behavior as dishonorable in military terms, is quite remarkable considering that narratives of heroism, self-sacrificing courage, and military glory have largely become irrelevant for Western military security and within Western societies at large.

To examine this reappearance of cowardice — as an accusation and reproach —in military confrontations, I shall now expand the relationship between the meaning of cowardice as used by in these accusations on the one hand, and the understanding of the concept of cowardice as outlined above, on the other hand. This will be followed by a consideration of some normative implications of the term's revival within military security policy. Thus, the main focus of this section is not on the-quite obvious - cathartic political effect of the knee-jerk phrase of the cowardly attack. Rather, the purpose here will be to shed some light on the revived use of the term and idea of cowardice as a speech act (according to Searle 1972) and to discuss the semantic content and the normative consequences of its modified reanimation for the political and societal discourse on military security and, as a consequence, for post-heroic security culture.

The almost standardized usage of the cowardice-accusation to stress the enemy's villainy is obviously at odds with the meaning of the term as outlined above, and this with regard to both its general meaning and its more specific use in the context of military security and armed conflict. In contrast to the semantic content of

\footnotetext{
12 For some examples from Germany, see the statements made by the former German Chancellor Gerhard Schröder, former Ministers of the Interior Thomas de Maizière, the former Minister for Foreign Affairs and today's Federal President Frank-Walter Steinmeier, the former Minister for Economics and Technology Rainer Brüderle, the former Minister of Defense Franz Josef Jung, and Chancellor Angela Merkel in Sirleschtov (2003), Deutsche Welle (2007), Frankfurter Rundschau (2008), tagesschau.de (2009, 2010), Reichelt (2011), Gebauer (2011), and Löwenstein (2011), respectively. There are manifold examples from outside Germany, too. For instance, The Independent noted after a series of attacks and suicide bombings that "Foreign Secretary William Hague has condemned as 'cowardly' a series of attacks in Iraq" (Barrett 2011), while Western allied Saudi Arabia sees the recent bombings of Saudi oil facilities as cowardly attacks (Spiegel Online 2019). For examples of the cowardice-accusation from an international organization, see the press statements of the United Nations Security Council $(2018,2019)$ after suicide bombings in Kabul in 2018 and in 2019. See also BBC (2017) for the Afghan President's condemnation of a suicide attack close to the German embassy in Kabul as cowardly. As Holland (2011: 100) highlights with regard to the US anti-terrorist approach after 9/11, "[o]ne frequently deployed strategy was to contrast this [American, A.V.] exceptionalism-as manifest in the individual acts of heroism witnessed on 9/11 — with the cowardice of America's enemies." See also Jarvis and Holland (2014: 426, 441).
} 
cowardice, the only purpose of the cowardly attack-mantra is to emphasize how disgraceful such attacks are. Thus, its use can be seen as contributing to, and being a part of, the tendency to demonize political and military opponents in violent conflicts. These accusations of cowardice conjure up only the pejorative connotation of the term and, thus, seem to be aimed at a cathartic and propagandistic effect that delegitimizes or even dehumanizes the enemy (see on this Steuter and Wills 2010: 159, see also Holland 2011: 100f; Jarvis and Holland 2014: 437, 441). ${ }^{13}$ However, apart from its dishonorable connotation, this particular use of the term does hardly jibe with any of the phenomenological definitions or the characteristic traits of cowardice discussed above. When considering that accusations of cowardice are usually made in response to attacks on own or allied troops in situations of asymmetric conflict and guerrilla warfare such as the wars in Iraq and Afghanistan, it quickly becomes clear that the enemy combatants did not lack determination and resolve, that their actions were not motivated primarily by fear of personal harmespecially not in cases of suicide attacks - and that the attacks were not an expression of defeatism on the part of the enemy. Given that the armed forces of Western countries are considerably stronger in terms of conventional military power ${ }^{14}$-a fact reflected not least in the significantly larger number of casualties among enemy combatants in all asymmetric conflicts with Western involvement-it is difficult to see how the accusation of cowardice might correspond to the meaning and semantic content of the term. Not even the first, more formal aspect of cowardice, that it is a primarily mental characteristic or psychological tendency, seems to fit this continual accusation of cowardice directed at the enemy. In contrast, when used to make accusations in the way outlined here, the term cowardice does not describe an individual psychological trait, but much rather a characteristic trait of the enemy's strategy. The cowardice-reproach portrays cowardice as a part of the enemy's way of fighting and of his political and military rationality - and through this makes cowardice a matter of genuine, strategic relevance for military security policy.

Thus, although the usage of the cowardice-accusation does not correspond to the semantic content of the term, but only to its pejorative connotation, it implies a revaluation and reconstitution of cowardice as a phenomenon with security relevance. However, the new structural importance associated with cowardice differs considerably from its significance in military history and current military law. In fact, the current upgrade in security relevance in two crucial respects contradicts

\footnotetext{
13 Based on Kant's sixth preliminary article for perpetual peace (Kant 1796: 12), the phenomenon of moral demonization and delegitimization of the enemy has recently gained increased attention in IR. The tendency of Western governments to morally and ethically disqualify their opponents and brand them as the ultimate evil has been diagnosed and discussed in particular in the context of liberal interventionism and democratic warfare. See Casebeer (2004), Steuter and Wills (2010), Chandler (2014), Geis and Wunderlich (2014), Hayden (2014), and Müller (2014). For a broad analysis of the topic, see Schillings (2017). See Vasilache (2019b: 148-152) for the relation between the-in most cases-normative justification of liberal wars on the one hand and the tendency of demonization of the enemy on the other hand.

14 Resorting to terrorist combat strategies is basically always the result of military inferiority. Already before the current rise of asymmetric conflicts, it can be observed that actors that are relatively weak in terms of conventional military power, and are therefore likely to lose a conventional confrontation, tend to apply tactics and techniques of terrorist and/or guerilla warfare.
} 
the traditional as well as the current legal depiction of cowardice in military security politics. Firstly, today's accusations of cowardice after successful attacks are directed at a different carrier of the trait of cowardice-and, secondly, the potential of cowardice changes as well. Compared to the traditional military problematization (see Foucault 2008) of cowardice in the heroic narrative and in military law, the current usage of the term does not address the own military any longer, but the enemy. At the same time, cowardice is supposed to have a completely different-actually opposed-security impact. Cowardice is no longer seen as a risk within and for the own troops, but as a resource of the enemy. The enemy's cowardice manifests in, is realized through, and builds the basis for, his attacks and successes. Rather than having to worry about potential cowards in own ranks, the own troops are faced with the challenge of the enemy's cowardice. Thus, in order to give substance to the somewhat implausible claim that cowards, of all people, are a major threat to military organizations equipped with an arsenal of high-tech weaponry, cowardice can no longer be understood in the sense outlined above, but both its carrier and its potential are redefined. In contrast to the semantic meaning of cowardice, when addressed as an accusation to the military adversary it is no longer aimed at "insulting the enemy for cowardice, weakness and inferiority as fighters" (Molvær 1991: 184), but becomes a sign of the enemy's power, albeit an illegitimate and dishonorable kind of power that should be spurned. In short, in the formulaic expression of the cowardly attack, cowardice is transformed from a possible weakness of one's own forces to a particular strength of the enemy.

It is particularly remarkable that the reproach for dishonorable, cowardly conduct is brought forward in post-heroic societies. Post-heroic societies are-with good reason-skeptical about discourses of military heroism and narratives of soldierly self-sacrifice. They support and maintain their military organizations "not so much with honor as [...] with money" (Münkler 2007: 752, own translation). The term and accusation of cowardice refers back to, and is based on, the ideational correlate of a heroic security discourse, which has largely become irrelevant in Western societies. Thus, the continued use of the cowardice-phrase to accuse the enemy of dishonorable conduct is a discursive anachronism that is at odds with the professionalized and technology-oriented security culture that characterizes most Western societies.

One might argue that such accusations of cowardice would not be quite as anachronistic if they were made only in internal communications between the government and the military or within the armed forces because, as Münkler notes, it is not unusual for military organizations "to have features that are typical of heroic communities" (2007: 752, own translation). However, from the perspective of the armed forces the enemy's cowardice and lack of courage cannot plausibly be framed as his strength and, thus, cannot possibly be regarded as a problem-but would actually be just a stroke of luck. This is why the discursive perpetuation of the enemy's cowardice cannot make sense and does not serve any purpose in internal military communication, 
either. ${ }^{15}$ Thus, while the cowardice-reproach both is embedded in and revives heroic military logics, its semantic emptiness and paradoxical framing as an accusation of the enemy's strength do not work within military rationalities. It is therefore not surprising that, unlike government representatives, representatives of the armed forces generally avoid making accusations of cowardice against the enemy. In fact, the discursive reiteration of the enemy's cowardice might be regarded and interpreted as insulting and cynical within the own troops. Consequently, the mantra of the enemy's cowardice is not used in communication with the armed forces or within the military, but when governmental representatives and other political actors address a broader, civilian audience. Since the cowardice-accusation against the enemy is aimed at the general public in post-heroic societies and security cultures, the anachronistic character of accusations of cowardice is, however, particularly striking.

Now, if we regard the end of a militarized and heroic security culture as a normative achievement and as a development that should not be reversed, then the continued and formulaic use of the cowardice narrative should give us pause. For, although accusations of cowardice do not relate to the actual semantic content of the word but conjure up only its negative and pejorative connotation, it is precisely this specific emphasis of soldierly honor, or of the lack thereof, that aids in the revival of heroic logics and implicates a throwback to narratives and discourses suffused with ideals of military virtue that are now considered obsolete by vast majorities in most Western societies. The perpetuated accusations of cowardice, even if they do not convey the semantic meaning of cowardice but solely its dishonorable connotation, originate from, relate to, and are embedded in a heroic discursive field that invokes ideals of soldierly courage, sacrifice, honor, and shame. Thus, the mantra of the enemy's cowardice re-introduces rationalities and ideals of military valor and soldierly honor to security discourses in Western societies that have come a long and violent way to overcome a heroic and militarist security culture.

However, in addition to this general argument, there is another, more concrete reason why the perpetuated accusations of cowardice lead to normative problems. The indiscriminate use of the formulatic expressions of cowardly attacks or acts of cowardice to describe attacks on troops and/or security targets and infrastructure in a military conflict, ${ }^{16}$ attacks on civilians and civilian infrastructure, ${ }^{17}$ and criminal

\footnotetext{
15 Just as an illustrative example of the traditional understanding of cowardice within the armed forces, see the statements of two (anonymized) German soldiers called "Waldemar" and "Jan" in Afghanistan highlighting that the war is less hard and menacing because of the Taliban's cowardice (see Seliger 2011: 5). In this statement (published in "Die Bundeswehr," which is the media outlet of the largest and influential association of German soldiers "Deutscher Bundeswehrverband"), the enemy's cowardice is amost welcome - sign and expression of his military weakness and inferiority.

16 Again, see Sirleschtov (2003), Deutsche Welle (2007), Frankfurter Rundschau (2008), Löwenstein (2011), tagesschau.de (2009, 2010), Reichelt (2011), Gebauer (2011), BBC (2017), Reuters (2019), Holland (2011: 100), and Jarvis and Holland (2014: 426, 441).

17 See, for example, accusations of cowardice made by German Chancellor Angela Merkel, former Minister of Foreign Affairs Guido Westerwelle, and former Minister of Economic Cooperation and Development Dirk Niebel in response to an attack on a German aid worker in Afghanistan in Presse- und Informationsamt der Bundesregierung (2010). See also Barrett (2011); United Nations Security Council (2018; 2019). As reported by the United Nations (2014), "[t]he head of the United Nations Assistance
} 
offenses ${ }^{18}$ leads to the blurring of the lines between combat operations, terrorist acts, and crimes; between cross-border conflicts and (transnational) crimes; and, most importantly, between combatants and civilians. The discursive and conceptual blurring of these categorical distinctions by Western actors is, however, not only a discursive phenomenon and problem. Much rather, it is mirrored in empirical reality and in current security policies. As an example, one could name the ongoing Operation Atalanta off the coast of Somalia that has been "extended to include the inland region as well" (Bundesregierung 2012, own translation). With the purpose of territorializing the mission, the extension of this mandate blurs the line between what was essentially a police operation to stop piracy off the coast of Somalia and enforce international maritime law on the one hand and a military intervention in civilian areas on the other hand-with all the predictable consequences that the establishment of a combat and war zone has for the civilian population.

The erosion and suspension of the systematic distinctions between military combat operations and terrorist acts, between cross-border conflicts and (transnational) crime, between military and police, and in particular between combatants and civilians is actually a characteristic trait of asymmetric warfare and an strategic objective of belligerent parties who are rather weak in terms of conventional military power and who are likely to be defeated in a military confrontation (see Münkler 2002). However, the permanent and indiscriminate cowardiceaccusation by Western actors-regardless of the context, situation, committing actors, and targets of an attack - also contributes to the blurring of these categorical lines, especially of the line between combatants and civilians. When a terrorist attack with remote detonated explosives against civilians is equated with suicide attacks against military forces or infrastructure, when both examples are to be considered indiscriminately as analogue acts of cowardice, the mentioned systematic distinctions become blurred, uncertain, and finally suspended. Such a discursive framing unwittingly but inevitably reproduces and, although unintentionally, thereby supports and subscribes to the strategy of belligerents in asymmetric conflicts to erode these distinctions. Rather than insisting on clear systematic dividing lines between legal status categories whenever possible, ${ }^{19}$ especially when dealing with enemies engaged in asymmetric warfare, sweeping accusations of the enemy's cowardice contribute to the erosion of these lines ${ }^{20}$-thus

Footnote 17 (continued)

Mission for Iraq (UNAMI) has denounced the "vicious and cowardly" suicide attack" against a university in Baghdad. See Reuters (2019) for the accusation of cowardice after suicide bombings against civilian targets as well as security actors in the context of the 2019 Afghan elections. See also Holland (2011: 100) and Jarvis and Holland (2014: 426, 441).

18 For example, the reproach of a cowardly attack may concern cases as diverse as acts of piracy off the Horn of Africa (Fengler 2010) or the malicious damage of property (Hutterer 2012).

19 This does not contradict the general acknowledgment that state military organizations and military strategies have to, and in fact do, change and respond to the fact that many current armed conflicts do not have a strictly interstate structure anymore and that today a broad variety of different types of actors are involved in inter- and transnational military and security policy.

${ }^{20}$ By classifying the suicidal attack on German soldiers on May 19, 2007, in Afghanistan as a "perfidious murder" (Merkel in Deutsche Welle 2007), the German Chancellor provided an almost paradigmatic example of the indiscriminate blurring of all these categories. Suffice it to say that by steadfastly refusing 
undermining international legal norms that were established to prevent the relentless expansion of military violence in the first place. By indifferently equating attacks on armed forces in combat with intentional and targeted attacks on civilians, the possibility to systematically discern different situations, contexts, and legal frameworks of the use of force is basically suspended. Quite obviously, the normative consequence of such a systematic indistinguishability-particularly between combatants and civilians - consists both in a trivialization of armed conflicts and in a relativization of terrorist and/or criminal violence. Indiscriminately condemning attacks on own or allied troops in operational zones and attacks on purely civilian targets as equally cowardly, dishonorable, and illegitimate equates very distinct phenomena of violence-and discursively follows the logics and strategies used by terrorist groups in equating military and civilian targets.

The blurring of the systematic distinctive line between combatants and civilians implied by the cowardice-mantra is an expression of normative relativism with regard to civilian victims, but also in view of the risks taken by military personnel who put their lives on the line. From the perspective of military organizations and their members, such a relativistic equation of combatants and civilians must actually be understood as a trivialization and a lack of recognition of a high-risk duty. As already noted, the contemporary rhetoric of cowardice is found neither in internal military discourses nor in communications between the government and the military—since, again, within a more traditional and heroic "military grand narrative" (Wasinski 2011) that takes the semantic meaning of the term cowardice seriously, the enemy's cowardice would be a stroke of luck. In addition, members of the armed forces can be expected to refuse discourses or narratives that trivialize the particular duty and risk faced by soldiers. On the contrary, we must assume that military organizations and members of the military will insist on the political and societal recognition that soldiers are not defenseless victims who are sacrificed, but are professionals in a high-risk environment who make sacrifices when fighting a threatening enemy.

Interestingly, this lack of recognition of military professionalism and soldierly risk implied by the discursive equation of combatants and civilians seems to be countered, at least occasionally, by resorting to semantic and linguistic conventions from a more traditional military terminology. In Germany, government officials and some media outlets tend to revitalize the verb "fallen" (analogous to the English usage of the verb "to fall" and the French verb "tomber" in

Footnote 20 (continued)

to call the deployment of Bundeswehr troops in Afghanistan a war operation, the German government has also been contributing to the blurring and thus to the erosion of these lines. The few terminological concessions that German politicians have made in this respect include that there are "war-like conditions" (former Minister of Defense zu Guttenberg and Chancellor Merkel, see FAZ 2009, own translation) - though only "from the perspective of our soldiers", only "in parts of Afghanistan", and not without adding that "the notion of war from traditional international law does not apply to the present situation" (Merkel in FAZ 2009, own translation) — and the statement that many soldiers in Afghanistan were in a situation "like war", "but not all of them and not all the time" (former Minister of Defense de Maizière in Hebestreit 2011, own translation). 
military contexts) when speaking about soldiers and to use the expression "getötet werden" ("to be killed") to refer to civilian and non-soldierly deaths (see, e.g., Gebauer 2011; Reichelt 2011). Combined with the cowardice-mantra, this semantic convention implies and accentuates that soldiers-in active voice and in active fulfillment of duty - die in action through acts of cowardice, whereas civiliansin passive voice and as passive objects-are killed by acts of cowardice. Following this terminology and semantic logics, enemy attacks on one's own troops are equivalent to attacks on civilians in that they are cowardly, which emphasizes the illegitimate character of the enemy's strategy. At the same time, this terminology highlights the determined and active performance of soldiery duties of the own armed forces, which is semantically honored and distinguished from the fate of passive civilian victims. This convention of speech can be seen as ambivalent attempt to accommodate the cowardice-mantra that is dysfunctional within military discourses to the recognition requests from military organizations and their members. Thereby, it consists in, and further contributes to, the discursive reactivation and revival of heroic military narratives and logics.

\section{Summary and Concluding Remarks}

Despite the particular role of fear and anxiety in classical state theory and in theories of IR-particularly in (neo-)realist traditions-cowardice has been given hardly any consideration in IR and international security studies. At first glance, this lack of interest is not surprising given that cowardice has lost its material relevance to the security politics of many, in particular Western states. However, since cowardice - as a reproach to adversary actors in violent conflicts- has been enjoying a revival in political communication, it is a worthwhile endeavor to think about the relationship between cowardice and military security in more general, systematic terms. The presented heuristic reflections are based on the premise that the revival of cowardice in communications on military security should be taken seriously and not be shrugged off as an irrelevant phrase with a purely cathartic or propagandistic impact. What Kratochwil (1982: 2) highlighted with regard to the notion of interest, holds true as well for the notion of cowardice: "We cannot eliminate with impunity the part of political reality for which the term stands" (1982: 2). Apart from the fact that cowardice-accusations are used routinely and consistently by politicians on basically all sides of the political spectrum, it would be poor judgment not to take governments and political elites seriously when it comes to issues of security politics and military force.

Based on a discussion of the meaning of the term both in everyday use and in its military connotation, it turns out that, today, cowardice does not play a functional role in the security policies and security cultures of Western societies any more. Ideals and narratives of heroic soldierly braveness, sacrifice, and honor as well as their negative correlate of "cowardice in the face of the enemy" are no longer of much relevance to post-heroic societies, in which military security is mainly based on the idea of technological superiority and on the deployment of highly trained and specialized military professionals. If cowardice ever does 
become an empirical issue in the context of the military of modern, post-heroic societies, it is one of military criminal law and has the status of an individual dereliction of official duty, without strategic or further political or collective implications for security policy at large.

In remarkable contrast to this development, we can observe that cowardice has recently seen a revival in governmental communications in the context of military conflicts. The formulaic expression of the cowardly attack is not restricted to terrorist attacks on civilians or to acts of violence outside war zones. Much rather, governments and government representatives tend to use it almost reflexively and basically after every attack on their own or allied troops in armed conflicts, especially in situations of asymmetric conflicts and wars. When the notion of cowardice is used in this way, it contains only one of the six characteristic aspects of cowardice outlined above - that is, its negative and pejorative connotation, which serves as an insult to the honor of those who are described in this way. Condemning enemy attacks as acts of cowardice frames such incidents as particularly despicable examples of the opposite side's wickedness and illegitimacy. However, apart from the dishonorable connotation, the current cowardice-mantra stands in direct opposition to all the other characteristic aspects of cowardice, which makes the notion of cowardice, in semantic terms, an empty signifier. ${ }^{21}$ At the same time, this revival of cowardice in security policy communication transforms the meaning of cowardice in two systematic ways and implies both a change of addressee and a change of the potential of cowardice. Cowardice is no longer regarded as a menace for and within the own troops that might weaken their morale and combat power. Rather, the enemy is now the one being accused of cowardice-with cowardice being seen not as a weakness anymore, but as an attribute of the enemy's strength. In short, cowardice turns from a potential own weakness to the adversary's strength.

This reanimation of cowardice in the context of military security discourses has normative consequences. Although the routine use of the formulaic phrase of cowardly attacks does neither correspond to the semantic meaning of the term nor to the traditional military impact of cowardice, it nonetheless originates from the semantic and discursive context of military heroism. As a speech act and as a particular way of problematizing military and soldierly behavior, this return of cowardice contributes to the discursive revival of heroic logics and narratives, which lags behind the state of debate in post-heroic security cultures in which military ideals of soldierly honor and heroism have already been overcome, at least outside military organizations.

\footnotetext{
21 Nota bene: This in no way implies that the use of asymmetric strategies and tactics is a sign of heroism, courage, or honorableness. To draw such a conclusion would mean to insist on perpetuating a heroic security discourse, the kind of which-for very good historical and normative reasons-has largely become irrelevant in most Western societies. The point I am making here is that the cowardice-mantra in military conflicts is misleading since the phenomena, incidents, and events routinely described as acts of cowardice simply do not reflect any of the aspects that are characteristic of cowardice, but only its negative and dishonorable connotation.
} 
While the cowardice-reproach is embedded in and revives heroic military logics, it is void of its actual meaning and depicts cowardice as a reproachable strength of the enemy. Such a rather paradoxical framing, however, cannot be considered plausible from the perspective of soldiers and military organizations. This leads to the not less paradoxical situation that this particular framing and reanimation of cowardice, on the one hand, relies on, and is embedded in, heroic rationalities and narratives, which are merely anachronistic in modern, post-heroic societies-while, on the other hand, it is a dysfunctional and inconsistent speech act within military organizations, that in principle are or could be receptive to heroic rationalities of soldierly honor.

In addition to the more general normative implication of a revival of heroic narratives and to the paradoxical and inconsistent implications of this revival, the continuous and indiscriminate use of the term cowardice to describe both enemy attacks on soldiers in armed conflicts and violent acts or criminal offenses against civilian targets contributes to discursively undermining international norms. The undifferentiated equation of different phenomena of violence as cowardly attacks blurs the distinction between war and peace, military and police, combat and crime, and, in particular, between civilians and combatants. These categorical and systematic distinction lines are and have always been fragile. Still, they are essential in international law and the only existing provisions against the unrestrained expansion, escalation, and brutalization of and in military conflicts. The reappearance of cowardice and its completely undifferentiated shape contributes to discursively blurring, suspending, and revoking these distinctions. Thereby, the current cowardice-rhetoric, even if unintentionally, follows, reproduces, and in fact confirms the logics of asymmetric groups and adversaries, whose very strategy consists in weakening and suspending these systematic and legal categories and differences.

Acknowledgments Open Access funding provided by Projekt DEAL.

Open Access This article is licensed under a Creative Commons Attribution 4.0 International License, which permits use, sharing, adaptation, distribution and reproduction in any medium or format, as long as you give appropriate credit to the original author(s) and the source, provide a link to the Creative Commons licence, and indicate if changes were made. The images or other third party material in this article are included in the article's Creative Commons licence, unless indicated otherwise in a credit line to the material. If material is not included in the article's Creative Commons licence and your intended use is not permitted by statutory regulation or exceeds the permitted use, you will need to obtain permission directly from the copyright holder. To view a copy of this licence, visit http://creativecommons.org/licen ses/by/4.0/.

\section{References}

Alexandra A, Baker DP, Caparini M (eds) (2008) Private military and security companies: ethics, policies and civil-military relations. Routledge, London

Aradau C, Blanke T (2010) Governing circulation: a critique of the biopolitics of security. In: de Larrinaga M, Doucet MG (eds) Security and global governmentality: globalization, governance and the state. Routledge, London, pp 44-58

Aradau C, Van Munster R (2007) Governing terrorism through risk: taking precautions, (un)knowing the future. Eur J Int Rel 13(1):89-115 
Azubuike S (2006) To appease or to concede? Contrasting two modes of accommodation in international conflict. Int Rel 20(1):49-68

Barber BR (2002) Ein Krieg “jeder gegen jeden”: Terror und die Politik der Angst. Aus Politik und Zeitgeschichte 18:7-16

Barber BR (2003) Fear's empire: terrorism, war and democracy. Norton, New York

Barrett E (2011) William Hague condemns 'cowardly' attacks in Iraq. The Independent, December 22. https://www.independent.co.uk/news/uk/politics/william-hague-condemns-cowardly-attacks-iniraq-6280598.html. Accessed 21 Jan 2020

Bauman Z (2006) Liquid fear. Polity Press, Cambridge

BBC (2017) Kabul bomb: Afghan leader condemns 'cowardly' attack, June 1. https://www.bbc.com/ news/world-asia-40109568. Accessed 21 Jan 2020

Blocq D (2010) Western soldiers and the protection of local civilians in UN peacekeeping operations: is a nationalist orientation in the armed forces hindering our preparedness to fight? Armed Forces Soc 36(2):290-309

Booth K, Wheeler NJ (2008) The security dilemma: fear, cooperation and trust in world politics. Palgrave Macmillan, Houndmills

Brinkkötter HO (1983) Feigheit: Die Verletzung der soldatischen Gefahrtragungspflicht als Wehrstraftatbestand in rechtshistorischer Betrachtung: Ein Beitrag zur Wehrstrafrechtsgeschichte von der Zeit der Germanen bis zum 18. Jahrhundert mit einem Ausblick. PhD thesis, Philipps University, Marburg

Brockhaus' Konversationslexikon (1893-1897) Feigheit. In: Konversations-Lexikon, Vol. 6: Elektrodynamik - Forum, 14th edn. F. A. Brockhaus, Leipzig, pp 632-633

Bundesregierung (2012) Auslandseinsatz: Ausrüstung somalischer Piraten am Strand zerstören. https:// archiv.bundesregierung.de/archiv-de/dokumente/ausruestung-somalischer-piraten-am-strand-zerst oeren-392570. Accessed 21 Jan 2020

Bundesversammlung der Schweizerischen Eidgenossenschaft (1927) Militärstrafgesetz (MStG) vom 13. Juni 1927 (Stand am 1. Juli 2019). SR-Number: 321.0. https://www.admin.ch/opc/de/classified -compilation/19270018/201907010000/321.0.pdf. Accessed 23 Jan 2020

Buzan B, Hansen L (2009) The evolution of international security studies. Cambridge University Press, Cambridge

Buzan B, Wæver O, de Wilde J (1998) Security: a new framework for analysis. Lynne Rienner, Boulder

Casebeer WD (2004) Knowing evil when you see it: uses for the rhetoric of evil in International Relations. Int Rel 18(4):441-451

Chandler D (2014) Beyond good and evil: ethics in a world of complexity. Int Polit 51(4):441-457

Cramer JK (2009) Militarized patriotism and the success of threat inflation. In: Thrall AT, Cramer JK (eds) American foreign policy and the politics of fear: threat inflation since 9/11. Routledge, London, pp 135-152

Daase C, Rauer V, Offermann P (2012) Sicherheitskultur: Soziale und politische Praktiken der Gefahrenabwehr. Campus, Frankfurt am Main

Der Spiegel (2014) Neue Verteidigungsministerin: Wie von der Leyen die Bundeswehr reformieren will, January 12. https://www.spiegel.de/politik/deutschland/ursula-von-der-leyen-will-bundeswehr -familienfreundlicher-machen-a-943066.html. Accessed 21 Jan 2020

Deutsche Welle (2007) Reaktionen: 'Perfider Mord', May 19. https://www.dw.com/de/reaktionen-perfi der-mord/a-2543569. Accessed 10 Feb 2020

Deutscher Bundestag (1957) Wehrstrafgesetz in der Fassung der Bekanntmachung vom 24. Mai 1974 (BGB1. I S. 1213), das zuletzt durch Artikel 10 Absatz 8 des Gesetzes vom 30. Oktober 2017 (BGB1. I S. 3618) geändert worden ist. Berlin: Federal Ministry of Justice and Consumer Protection. http://www.gesetze-im-internet.de/wstrg/WStG.pdf. Accessed 21 Jan 2020

Dillon M, Neal AW (eds) (2008) Foucault on politics, security and war. Palgrave Macmillan, Houndmills

Dillon M, Reid J (2009) The liberal way of war: killing to make life live. Routledge, London

DoD (2012) Sustaining U.S. global leadership: priorities for 21st century defense. United States Department of Defense, Washington, D.C. https://archive.defense.gov/news/Defense_Strategic_Guidance. pdf. Accessed 21 Jan 2020

DTV-Lexikon (1992) Feigheit. In: dtv-Lexikon, Vol. 5: Eit - Fle. F. A. Brockhaus. Deutscher Taschenbuch Verlag, Munich, p 252

FAZ (2009) Bundeswehr-Einsatz: Merkel: "Kriegsähnliche Zustände" in Afghanistan. Frankfurter Allgemeine Zeitung, November 13. http://www.faz.net/aktuell/politik/inland/bundeswehr-einsatz-merke 1-kriegsaehnliche-zustaende-in-afghanistan-1882100.html. Accessed 21 Jan 2020 
Fengler D (2010) Piraterie vor Somalia: Soldaten befreien Hamburger Containerfrachter. Hamburger Abendblatt, April 6. http://www.abendblatt.de/hamburg/article1446245/Soldaten-befreien-Hambu rger-Containerfrachter.html. Accessed 21 Jan 2020

Foucault M (2008): Diskurs und Wahrheit: Die Problematisierung der Parrhesia. Berkeley-Vorlesungen 1983. Merve, Berlin

Frankfurter Runschau (2008) Kundus: Taliban töten deutschen Soldaten, August 27. https://www.fr.de/ politik/taliban-toeten-deutschen-soldaten-11583140.html. Accessed 10 Feb 2020

Friedrichs J (2010) The privatization of force and its consequences: unintended but not unpredictable. In: Daase C, Friesendorf C (eds) Rethinking security governance: the problem of unintended consequences. Routledge, London, pp 176-197

Garland D (2002) The culture of control: crime and social order in contemporary society. Oxford University Press, Oxford

Gebauer M (2011) Nordafghanistan: Bundeswehrsoldat stirbt bei Bombenattacke. Spiegel Online, May 25. https://www.spiegel.de/politik/ausland/nordafghanistan-bundeswehrsoldat-stirbt-bei-bombe nattacke-a-764805.html. Accessed 21 Jan 2020

Geis A, Wunderlich C (2014) The good, the bad, and the ugly: comparing the notions of 'rogue' and 'evil' in international politics. Int Polit 51(4):458-474

Grondin D (2010) The new frontiers of the national security state: the US global governmentality of contingency. In: de Larrinaga M, Doucet MG (eds) Security and global governmentality: globalization, governance and the state. Routledge, London, pp 79-95

Hayden P (2014) Systemic evil and the international political imagination. Int Polit 51(4):424-440

Hebestreit S (2011) Truppenbesuch in Masar-i-Sharif: Wie im Krieg - mit Plastikmessern. Frankfurter Rundschau, March 27. https://www.fr.de/politik/krieg-plastikmessern-11401863.html. Accessed 21 Jan 2020

Hobbes T (1998) Leviathan oder Stoff, Form und Gewalt eines kirchlichen und bürgerlichen Staates: Herausgegeben und eingeleitet von Iring Fetscher, 8th edn. Suhrkamp, Frankfurt am Main

Hoffmann B (2002) Terrorismus: Der unerklärte Krieg. Fischer, Frankfurt am Main

Höglund AT (2003) Viewpoints: war on terrorism: feminist and ethical perspectives. Security Dialogue $34(2): 242-245$

Holland J (2011) 'When you think of the taliban, think of the nazis': teaching Americans '9/11' in NBC's The West Wing. Millennium 40(1):85-106

Hutchinson J (2009) Warfare and the sacralisation of nations: the meanings, rituals and politics of national remembrance. Millennium 38(2):401-417

Hutterer E (2012) Schaufenster eingeschlagen: Feiger Anschlag auf das Mühldorfer Wochenblatt. Wochenblatt, January 3. http://www.wochenblatt.de/nachrichten/muehldorf/regionales/MuehldorfWochenblatt-Fenster-Polizei-Hinweise-Schaufenster-Anschlag;art1174,86196. Accessed 21 Jan 2020

Iyer R (1986): The moral and political writings of Mahatma Gandhi, vol. I: civilization, politics and religion. Oxford University Press, New Delhi

Jabri V (2006) War, security and the liberal state. Secur Dial 37(1):47-64

Jarvis L, Holland J (2014) 'We [for]got him': remembering and forgetting in the narration of bin Laden's death. Millennium 42(2):425-447

Kant I (1796): Zum ewigen Frieden. Ein philosophischer Entwurf. Friedrich Nicolovius, Königsberg

Katzenstein PJ (1996) The culture of national security: norms and identity in world politics. Columbia University Press, New York

Khattak SG (1996) Security discourses and the state in Pakistan. Altern Global Local Polit 21(3):341-362

Kienscherf M (2011) A programme of global pacification: US counterinsurgency doctrine and the biopolitics of human (in)security. Secur Dial 42(6):517-535

Kierkegaard S (1912) Der Begriff der Angst. E. Diederich, Jena

Kierkegaard S (1962) Wider Feigheit. In: Paulsen A (ed) Der Pfahl im Fleisch: Sowie Wider Feigheit und Vom Gebet. Furche, Hamburg, pp 57-95

Kiersey NJ (2010) Neoliberal political economy and the Iraq war: a contribution to the debate about global biopolitics. In: de Larrinaga M, Doucet MG (eds) Security and global governmentality: globalization, governance and the state. Routledge, London, pp 61-78

Kiersey NJ (2011) Neoliberal political economy and the subjectivity of crisis: why governmentality is not hollow. In: Kiersey NJ, Stokes D (eds) Foucault and international relations: new critical engagements. Routledge, London, pp 1-24 
Kleinschmidt H (2009) The transformation of the European culture of security. Institut für Internationale Politik und Wirtschaft, Hamburg

Korte K-R (ed) (2015) Emotionen und Politik: Begründungen. Konzeptionen und Praxisfelder einer politikwissenschaftlichen Emotionsforschung, Nomos, Baden-Baden

Koschut S (2015) Macht der Gefühle. Zur Bedeutung von Emotionen für die sozialkonstruktivistische Diskursforschung in den IB. Zeitschrift für Internationale Beziehungen 22(2):7-33

Kratochwil FV (1982) On the notion of "Interest" in international relations. Int Org 36(1):1-30

Lentzos F, Rose N (2008) Die Unsicherheit regieren: Biologische Bedrohungen, Notfallplanung, Schutz und Resilienz in Europa. In: Purtschert P, Meyer K, Winter Y (eds) Gouvernementalität und Sicherheit: Zeitdiagnostische Beiträge im Anschluss an Foucault. Transcript, Bielefeld, pp 75-101

Löwenstein S (2011) Afghanistan: Deutscher Soldat bei Sprengstoff-Attentat getötet. Faz.net, May 25. http://www.faz.net/aktuell/politik/afghanistan-deutscher-soldat-bei-sprengstoff-attentat-getoetet1641362.html. Accessed 21 Jan 2020

Lummis CD (2006) The smallest army imaginable. Altern Global Local Polit 31(3):313-343

Martinsen F, Flügel-Martinsen O (eds) (2014) Gewaltbefragungen: Beiträge zur Theorie von Politik und Gewalt. Transcript, Bielefeld

Meyers Konversationslexikon (1885-1892) Feigheit. Meyers Konversations-Lexikon, vol. 6: Faidit bis Gehilfe, 4th edn. Verlag des Bibliographischen Instituts, Leipzig and Vienna, p 100

Molvær RK (1991) Environmentally induced conflicts? A discussion based on studies from the Horn of Africa. Bull Peace Prop 22(2):175-188

Mullen JD (1988) Kierkegaard's philosophy: self-deception and cowardice in the present age. University Press of America, Lanham

Müller H (2014) Evilization in liberal discourse: From Kant's 'unjust enemy' to today's 'rogue state'. Int Polit 51(4):475-491

Münkler H (2002) Die neuen Kriege. Rowohlt, Reinbek

Münkler H (2007) Heroische und postheroische Gesellschaften. Merkur: Deutsche Zeitschrift für europäisches Denken 61(700):742-752

Neocleous M (2012) "Don't be scared, be prepared": trauma-anxiety-resilience. Altern Global Local Polit 37(3):188-198

Parekh B (1988) Gandhi's concept of Ahimsā. Altern Global Local Polit 13(2):195-217

Presse- und Informationsamt der Bundesregierung. (2010) Afghanistan: Deutscher Entwicklungshelfer getötet. https://www.bundeskanzlerin.de/bkin-de/aktuelles/deutscher-entwicklungshelfer-getoetet391704. Accessed 21 Jan 2020

Reichelt J (2011) Der feige Anschlag in Afghanistan: Eine Soldatin ist unter den Verwundeten. Bild.de, May 29. http://www.bild.de/politik/ausland/afghanistan/attentaeter-sollte-kneip-schuetzen-18132 244.bild.html. Accessed 21 Jan 2020

Reuters (2019) Taliban attacks kill 48, Afghan leader unhurt as bomber targets rally (reporting by Abdul Qadir Sediqi, Hameed Farzad, Hamid Shalizi, writing by Paul Carsten; editing by William Maclean and Alex Richardson), September 17. https://www.reuters.com/article/us-afghanistan-electionblast/taliban-attacks-kill-48-afghan-leader-unhurt-as-bomber-targets-rally-idUSKBN1W20UA. Accessed 21 Jan 2020

Schillings S (2017) Enemies of all humankind: fictions of legitimate violence. Dartmouth College Press, Hanover

Schneckener U (2006) Transnationaler Terrorismus: Charakter und Hintergründe des "neuen" Terrorismus. Suhrkamp, Frankfurt am Main

Schneiker A (2010) Security Governance durch Verhaltenskodizes: Regulierung für private Sicherheits- und Militärfirmen. In: Ehrhart H-G, Kahl M (eds) Security Governance in und für Europa: Konzepte, Akteure, Missionen. Nomos, Baden-Baden, pp 151-166

Searle JR (1972) Speech acts: an essay in the philosophy of language. Cambridge University Press, Cambridge

Seliger M (2011): "Manchmal ist das schon ein Scheißjob". Die Bundeswehr: Magazin des deutschen Bundeswehrverbandes 2011(3):4-5

Selk V (2011) Angstpolitik: Terrorismus als politische Strategie. Diskurs Politikwissenschaftliche und geschichtsphilosophische Interventionen 7(1):10-35

Sharp G (1968) The need for a functional substitute for war. Int Rel 3(3):187-207

Simon J (2007) Governing through crime: how the war on crime transformed American democracy and created a culture of fear. Oxford University Press, Oxford 
Sion L (2006) "Too sweet and innocent for war"? Dutch peacekeepers and the use of violence. Armed Forces Soc 32(3):454-474

Sirleschtov A (2003) 4 Tote - aber Deutsche bleiben in Kabul. Der Tagesspiegel, June 8. https://www. tagesspiegel.de/politik/4-tote-aber-deutsche-bleiben-in-kabul/421110.html. Accessed 10 Feb 2020

Skoll GR (2010) Social theory of fear: terror, torture, and death in a post-capitalist world. Palgrave Macmillan, New York

Spiegel Online (2019) Konflikt im Nahen Osten: Saudi-Arabien fordert entschlossenere Reaktion auf Bombardierung von Ölanlagen, Spiegel Online, September 17. https://www.spiegel.de/politik/ausla nd/saudi-arabien-fordert-entschlossenere-reaktion-auf-bombardierung-von-oelanlagen-a-12872 91.html. Accessed 12 Feb 2020

Steuter E, Wills D (2010) 'The vermin have struck again': dehumanizing the enemy in post 9/11 media representations. Media War Conflict 3(2):152-167

tagesschau.de (2009) Anschlag in Afghanistan: Deutscher Soldat getötet, April 29. https://www.tages schau.de/ausland/afghanistan900.html. Accessed 10 Feb 2020

tagesschau.de (2010) ISAF-Einsatz in Afghanistan: Bundeswehrsoldat bei Anschlag getötet, October 7. https://www.tagesschau.de/ausland/bundeswehrafghanistan152.html. Accessed 10 Feb 2020

Thrall AT, Cramer JK (eds) (2009) American foreign policy and the politics of fear: threat inflation since 9/11. Routledge, London

Tonkin H (2011) State control over private military and security companies in armed conflict. Cambridge University Press, Cambridge

United Nations (2014) Iraq: UN envoy denounces 'vicious and cowardly' attack on university in Baghdad. UN News, April 21. https://news.un.org/en/story/2014/04/466532-iraq-un-envoy-denouncesvicious-and-cowardly-attack-university-baghdad. Accessed 21 Jan 2020

United Nations Security Council (2018) Security Council press statement on terrorist attack in Kabul, January 6. https://unama.unmissions.org/security-council-press-statement-terrorist-attack-kabul-4. Accessed 21 Jan 2020

United Nations Security Council (2019) Security Council press statement on terrorist attacks in Afghanistan, August 1. https://new-york-un.diplo.de/un-en/news-corner/190801-unsc-afghanistan/22372 90. Accessed 21 Jan 2020

USA (2012) Uniform code of military justice. Ithaca: Cornell University Law School, Legal Information Institute. http://www.law.cornell.edu/uscode/text/10/899. Accessed 21 Jan 2020

Valverde M, Mopas M (2004) Insecurity and the dream of targeted governance. In: Larner W, Walters W (eds) Global governmentality: governing international spaces. Routledge, London, pp 233-250

Vasilache A (2014) Great power governmentality? Coincidence and parallelism in the new strategic guidance for the US Department of Defense. Secur Dial 45(6):585-600

Vasilache A (2019a) Security in the sovereignty-governmentality continuum. Camb Rev Int Aff 32(6):681-711

Vasilache A (2019b) Fixing Missions. Überlegungen zu einem Typus des demokratischen Krieges zwischen liberalem Interventionismus und demokratischer Imperialität. In: Hausteiner EM, Huhnholz S (eds) Imperien verstehen: Theorien, Typen, Transformationen. Baden-Baden, Nomos, pp 129-168

Waldmann P (1998) Terrorismus: Provokation der Macht. Gerling Akademie Verlag, Munich

Walsh C (2014) Cowardice: a brief history. Princeton University Press, Princeton

Wasinski C (2011) On making war possible: soldiers, strategy, and military grand narrative. Secur Dial 42(1):57-76

Weiss T (2012) Fighting wars or controlling crowds? The case of the Czech military forces and the possible blurring of police and military functions. Armed Forces Soc 39(3):450-466

Weitz MA (2012) Desertion, cowardice and punishment. Essential Civil War Curriculum, April 2012. https://www.essentialcivilwarcurriculum.com/assets/files/pdf/ECWCTOPICDesertionCowardi ceandPunishmentEssay.pdf. Accessed 21 Jan 2020

Wolf R (2012) Der "emotional turn" in den IB: Plädoyer für eine theoretische Überwindung methodischer Engführung. Zeitschrift für Außen- und Sicherheitspolitik 5(4):605-624

Publisher's Note Springer Nature remains neutral with regard to jurisdictional claims in published maps and institutional affiliations. 